\title{
Rõžkovo virulaste rahvakalender
}

\begin{abstract}
Anu Korb
Teesid: Artiklis on vaatluse all 1803. aasta paiku asutatud vanima Lääne-Siberi luteriusuliste asunduse Rõžkovo virulaste (st eestlaste ja soomlaste) pärimusrühma kalendritavand. Käsitlus põhineb autori välitöödel aastatest 1999, 2000 ja 2004, võrdlusmaterjalina on kasutatud teistest Siberi eesti ja luteriusuliste asundustest talletatut. Tähtpäevade lõikes jälgitakse kogukonna kalendritavandis peamiselt 20. sajandi teisel poolel aset leidnud muutusi. Kodumaalt kaasa saadud eelkristlik ja/või luterlik traditsioon on mõjutatud nii hilisemast suhtlemisest emamaaga kui ka multikultuursete naabrite (peamiselt lätlaste ja venelaste) kombestikust. Võõraid kombestikuelemente on sobitatud oma traditsiooniga ja osaletud naabrite pühadel neid omaks pidamata. Kogukonna kalendritavandile on lisaks oma jälje jätnud aastatepikkune ideoloogiline surve, kultuuritöötajate suunav roll ja identiteeditaju muutused segaperekondades.
\end{abstract}

Märksõnad: diasporaa, eestlased, kogukond, multikultuuriline, rahvakalender, Siber, soomlased

Lääne-Siberi vanim luteriusuliste asundus Rõžkovo (asub tänapäevase administratiivjaotuse järgi Omski oblasti Krutinski rajoonis) tekkis 1803. aasta paiku Vene tsaarivalitsuse poolt väljasaadetud eestlastest, lätlastest, sakslastest, rootslastest, soomlastest ja ingerisoomlastest. Algusest peale elas külas ka venelasi (vt Korb 1998: 8). Rõžkovo on väljarännanute küladest ligi sada aastat vanem ja 20. sajandi lõpuks oli sellest saanud umbes 750 elanikuga paljurahvuseline ja -keelne küla. Enamusrahvuseks olid venelased, arvult teisele kohale jäid lätlased, kolmandale eestlased - kummalgi viimastest on nüüdki oma territoorium. Algsetest luteriusulistest olid külanõukogu statistikas esindatud veel sakslased. Keelelt ja kultuurilt lähedasi soomlasi ja eestlasi tähistas ühisnimetus virulane, vahet neil tihtipeale teha ei osatudki.

Käesolevas artiklis jälgitakse Rõžkovo virulaste kalendritavandis aset leidnud muutusi. Materjal põhineb autori aastatel 1999, 2000 ja 2004 samas 
külas läbi viidud välitöödel; piirkonnas varem töötanud uurijate (nt Ilja Lotkin, Alpo Juntunen) huvivälja see pärimusmaterjal ei kuulunud. Küll on aga autor võrrelnud oma ainest teistest Siberi eesti kogukondadest ja Kodu-Eestist talletatud tavanditeadetega.

Tõenäoliselt oli eesti rahvakalender kõige tähtpäevaderohkem ja mitmekesisem 17. sajandil (Vahtre 1991: 38-39; Hiiemäe 1998: 105). Seega võib oletada, et Siberisse saadetud eestlaste kalendripärimus oli sajandi võrra hiljem väljarännanute omast rikkalikum. Teisalt oli põhiosa väljasaadetuist mehed, asundus oli oma algusaegadel kurikuulus joomiste, kakluste ja röövimiste poolest (vt nt Granö 1905: 9) ning pole teada, kuivõrd esivanemate pühad ja tähtpäevad asunikele korda läksid. Väljarännanutele on seevastu iseloomulik püüd võõrsil oma kodumaad kopeerida ja kaasavõetud pärimuslik pagas, ka kalendritavand, omandab uuel asukohamaal olulisemagi koha kui emamaal.

Nädalapäevadest on Rõžkovo traditsioonis tänapäevalgi erilisel kohal pühapäeva pühitsemine. Ka külarahvale oluliste ja ilmastikust sõltuvate tööde perioodil, näiteks kartulivõtu ajal, on pühapäev töövaba. 2000. aasta septembrikuu esimesel laupäeval, töö alustamiseks igati sobival päeval, tehti minu külasviibimise ajal kartulivõtuga küll algust, kuid tööd jätkati alles esmaspäeval. Ajaloolase Lauri Vahtre arvates (1991: 17-18) on eestlased ja lätlased tundnud seitsmepäevast nädalat juba enne nende ristiusustamist. Pühapäev puhkepäevana on aga Siberi eestlastel siiani olulisemal kohal kui Kodu-Eestis (vt Hiiemäe 1998: 106), ehkki kommunistlik režiim püüdis omal ajal ka sellele lõpu teha (vt nt Jürgenson 2002: 235).

Rahvakalendri tähtpäevi peetakse Rõžkovos enamasti juuliuse ehk vana kalendri järgi:

A meil peatasse [pühasid] hiljem ku teil. No seitsmendal sellel janvaril meie joulud on. [---] Miski ta on olnd, et ta on jäänd see Siberi puol hiljemaks [---] (ERA, CD 451 (4) < Mari Blumfert (Särg), s 1922).

Kalendrireformi, mis ajaarvestuse uuele, gregooriuse kalendrile üle viis (Eestis toimus see ühtaegu Venemaaga aastal 1918), jättis vene õigeusu kirik aktsepteerimata. Sidemetest Eestiga teavad Rõžkovo virulased, et emamaal peetakse pühi varem, kuid suuremat segadust või pühade topeltpidamist, nagu mitmetes Siberi eesti asundustes tänapäeval tavaks (vt nt Korb 1998: 94), tuleb seal harva ette. Siiski on just viimastel aastatel, kui Kodu-Eesti ja Siberi sugulaste kirjavahetust asendab järjest enam telefoniside, juurdunud komme tähistada olulisemaid pühasid kodueestlastega üheaegselt - vastavalt Eestimaalt saadud näpunäidetele. 
Rõžkovo virulaste tähtsamad rahvakalendri tähtpäevad on tänapäeval jaanipäev, lihavõtted, suvistepühad ning jõulud ja aastavahetus. Minevikust mäletatakse paremini mardi- ja kadripäeva ning paastumaarjapäeva. Olnud tähtpäevadest teati nimetada veel kolmekuningapäeva, vastlapäeva, tuhkapäeva ja jüripäeva. Seega kokku mäletasid virulased umbes kahtteist rahvakalendri tähtpäeva. Näiteks etnoloog Piret Õunapuu toob tänapäeval Eestis enam tähistatavate tähtpäevadena esile kümme (vt Õunapuu 2001).

Koos venelastega pühitsevad Rõžkovo virulased veel kalmistupüha ehk kohaliku keelepruugi järgi raditelskit (vanemate mälestuspäev), kuid nn punased pühad virulaste traditsiooni ei juurdunud. Siinkohal on rahvakalendri tähtpäevi käsitletud alustades populaarseimast.

\section{Jaanipäev}

Jaanipäev on eestlaste ja soomlaste, samuti lätlaste tähtsaim suvepüha, mida iseloomustab eelkõige jaanitule tegemine, kodu ettevalmistamine pühadeks ja kalmistul haudade korrastamine. Jaanipäev on läbi aegade olnud ka Rõžkovo küla olulisim püha, mida on suurejooneliselt tähistanud nii eestlased, soomlased kui ka lätlased.

[---] Jaanipäeva, seda keige rohkemb oodeti. See oli keigi suuremb (ERA, CD 447 (9) < Anni Jurjeva (Ivanova), s 1928).

Jaanipäev on oma nime saanud Ristija Johannese järgi. Rõžkovos kutsutakse püha nelja erineva nimetusega: eestlaste jaanipäev, soomlaste juhannus ja venelaste Ivan Kupala lähtuvad pühaku nimest; seevastu lätlaste nimetus liigo (liiga) lähtub tunnuslikust läti jaanilaulu refräänist ja on enimlevinud.

Jaanipäev ei olnud viimase saja aasta jooksul usupüha, kuid üldiselt oli kombeks siiski ka kirikus käia. Nõukogude võimu kehtestamise järel (1917) alustati Siberiski süstemaatilist vanade rahvapäraste traditsioonide kui iganenute väljajuurimist (vt nt Aleksejevski 2004), kusjuures tugevama surve alla sattus religioonisümboolikaga seotu:

Üksvahe oli niiviisi, et jumalaraamatuid ja jumala pühasid ei tohi pidada, niisama oli see liigagi. [---] (ERA, CD 449 (17) < Olga Klaus, s 1922).

Just jaanipäeva tuntus surnute mälestuspühana ulatub tõenäoliselt eelkristlikku aega, kuid seostub kristlikus traditsioonis kiriku ja/või jutluse pida- 
misega kalmistul (Hiiemäe 1985: 26, 37-40) ja oli sellisena kommunistlikule režiimile vastuvõetamatu. Kirikute sulgemise ja usuelu keelustamise järel ei kadunud jumalasõna jaanikombestikust, vaid kiriklike talituste pidamine läks traditsiooni tundvate naiste kätte (vt nt Jürgenson 2000: 4244).

See juba ennembi, sellel, kui ütelda, jaanipääval. Siss seal daže oli nigu kirik. Kui meil enamb seda kirikut ei old, siss surnuaial pidas seda kirikud. [---] Vot vanamuorid, kes pidasivad seda jumalasonat nii [---] (ERA, CD 456 (1) < Mari Streit, s 1921).

Jaanipäeva palvetega pühitsemist Rõžkovo külas ei õnnestunud võimudel välja juurida. Inimesed keeldusid sel päeval tööle minemast (jaanipäev pole Venemaal riiklik püha) ja ametivõimud olid lõpuks sunnitud külarahvale vastu tulema - leppisid töövaba päevaga:

A näe, see oli kolhoosigi aeg, see püha meil oli, inimesed ei läindki [tööle], hakkasivad andma võhadnotti ka kord. [---] Kuuvendal ohtal aga see oli, see keigest suuremb pidu. Seitsmendal veel oli püha, a kaheksmandal enamb ei olnd, siis ju keik olivad tüöl [---] (ERA, CD 447 (9) < Anni Jurjeva (Ivanova), s 1928).

Küladevahelise suhtlemise tihenedes kasvas jaanipäeva kuulsus ka ümberkaudsete vene külade elanike seas, kuid selles nähti eeskätt eestlaste-lätlaste pidu:

Ivanov den', vot sie oli kovasti, seda dorožili kovasti, see siss olivad keik ümmer, mis külad olivad ja Kruutudest ja kust linnadest daže tulivad, meil kovasti pallu inimesi siin ikka olivad [---] (ERA, CD $466(27)<$ Emilia Ignatovitš (Sommer), s 1929).

[---] A siss, siss hakkasivad pidama ja nüit on kovasti patšot, see liiga, kovasti. Meil tänavaasta siin oli kole pallu rahvast, jah. Tulevad, näe Rõžkovo kõik liigale. Rehkendavad, et siin on läti küla ja iestlased segamini, et siin piab olema see liiga [---] (ERA, CD 449 (17) < Olga Klaus, s 1922).

Jaanipäev ja vahetult jaanipäevaeelne aeg on paljudel rahvastel tuntud taimedele omistatud maagilise mõjujõu poolest (vt nt Hiiemäe 1985: 20-21; Sahharov 1885: 90, 93; Propp 2004: 75; Hndwb IV: 715). Ka Rõžkovo virulased korjavad jaanipäeva paiku ravimtaimi ja teevad saunavihtu:

[---] Nii luomadel korjame enne jaanipäeva rohtuid.

- Mida te korjate siis?

- A keikisuguseid lilleid, et kui on vasikad, siis tšaiud tiede vasikatele... 


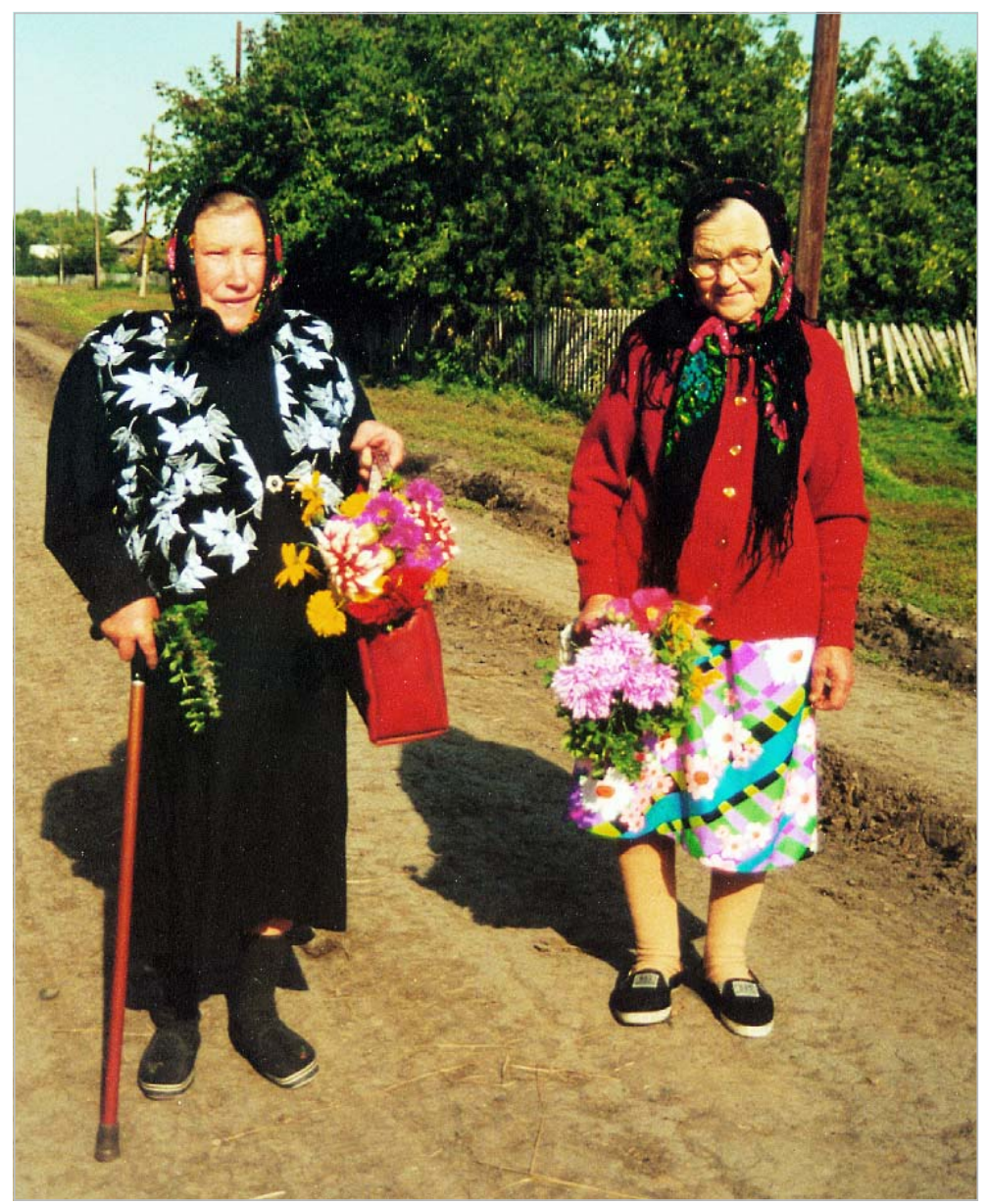

Foto 1. Pühapäeviti käiakse omaste haudadel. Ann Klaus ja Helena Bertis teel kalmistule. Anu Korbi foto 2000 (ERA, VF 3304).

- Nii et see on just enne jaanipäeva?

- Enne jaanipäeva. [---] Nied [taimed] kuivatavad ära ja vasikatel, kui on koht lahti [---] (ERA, CD 449 (10) < Anni Jurjeva (Ivanova), s 1928).

No ütlevad, et jaanipääva ohta ka tarvis teha vihta, et see on arstiviht. Seda vihta ju eri panime, et sie on arstiviht. [---]

- Aga mis hädadega siis seda arstivihta kasutati?

- No, a kui ütelda, selle vihtaga pidi saunas minna, kui oli sie kollane taud, želotš, kollane taud. [---] (ERA, CD 465 (25) < Poliina Sarantšuk (Blumfert), s 1927). 


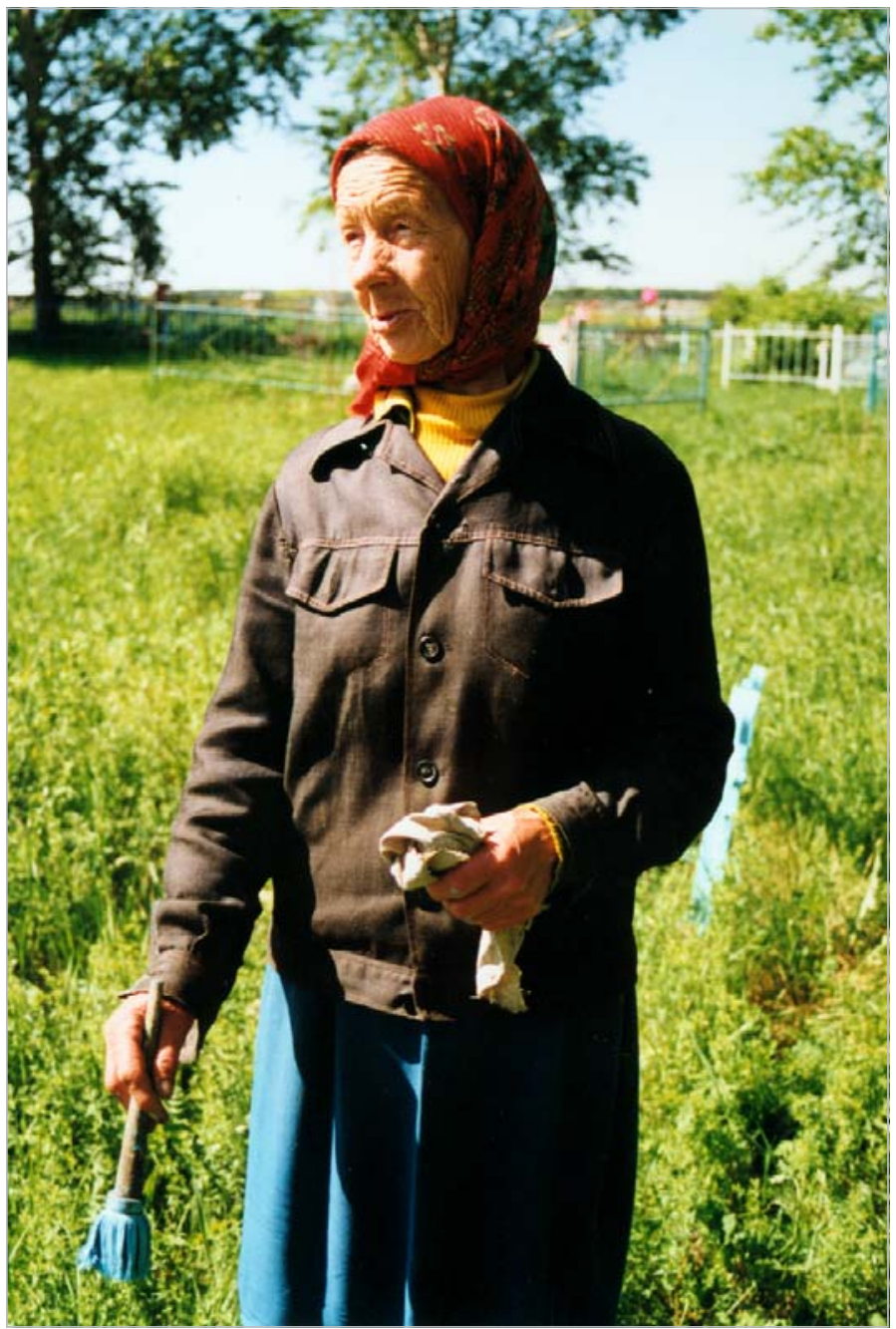

Foto 2. Enne jaanipäeva saavad omaste hauad korda. Mari Blumfert on tulnud hauapiirdeid värvima. Anu Korbi foto 1999 (ERA, VF 1738).

Siin toetab läti traditsioon virulaste oma - Lätimaalgi on arvatud jaanilaupäeval kogutud heinal ja kaselehtedel olevat ravitoime. Seevastu jaanikaste mõjujõudu, mis paljudel rahvastel, sealjuures ka Kodu-Eestis üldtuntud (Hiiemäe 1985: 21, 24), rõžkovolased ei tunne.

Väga populaarne on Rõžkovos olnud ka muistne suve vastuvõtu traditsioon (vt Hiiemäe 1985: 16) - kaskede-lillede kojutoomine:

[---] Tuppa panime lilled ja siss neid kaseoksaid murdsime, siss panime väravates molemates puoltes, kesk väravat. Ja lilled toime tuppa ja oksaid 
tuppa ka toime, et hia hais oleks [---] (ERA, CD 460 (18) < Hustin Enkvist (Juhanson), s 1913).

Lillepärg peas jaanitulele minek, mida tuntakse lõunapoolses Kodu-Eestis (Hiiemäe 1985: 20), on Rõžkovos ilmselt ka läti traditsioonist toitu saanuna üldtuntud:

Jaanipääva ohta tegivad kruonusi. [---] Inimesed tegivad, panivad endal pähe ohta.

- Ja sinna tehti siis palju, mitmed lilled pandi või ainult ühest lillest?

- Ei, mitmed, kui lilled miuksed olivad, mitmed lilled panivad. Käisivad. Noja jaaniohta juba, päeval käisime juba metsa, lilled korjasime [---] (ERA, CD 465 (24) < Poliina Sarantšuk (Blumfert), s 1927).

Metsalillede hauakääpale panemise kõrval oli Rõžkovos kombeks jaanipäeval ka ristidele pärgi ehk kroone meisterdada:

Ja siss jaaniüösse meil tehakse kruonid. Me ikka käisime metsas korjamas lillakalehtid ja lilleid, sis tegime kruonid. Muod oli meil mammal ikka enne, omadele surnuaeda viisime. Igaühel pidi kruon olema, iga ristile viisime kruonid [---] (ERA, CD 453 (1) < Emilia Naarits (Kodasma), s 1916).

Rõžkovolaste arvates ei tohtinud jaaniööd mingil juhul maha magada (lätlaste kohta vt Šmits 1940: 730-731).

[---] Kui jaaniohta, jaaniüö hakkad magama, nii terve aasta magad.

- Nii et jaaniöö ei tohtindki magada?

- Ei tohtind magada. Jah, jah. Vot i nüit onvad hommikust saadik. I nuored sial onvad see dom kul'tuura juures ka hommikust saadik [---] (ERA, CD 465 (22) < Poliina Sarantšuk (Blumfert), s 1927).

Sama motiiv esineb ka Eesti regivärsilise rahvalaulu tüübis "Kes ei tule jaanitulele" (ERIA 1969: 348).

Tuletegemine on kohaliku jaanipäevakombestiku oluline osa, tavaks on olnud tulede süütamine ka Rõžkovo jõel:

[---] No jaanipäev oli ka ennemalt niuke, niisama ilus, näe, seal jõe peal need tuled põlesivad, panneti, vie sisse tilkusivad nied tilgad. - Pierud panevad polema. - Siss nii kovasti oli ilus, et oli pallu neid poles. - Vie sisse panivad ülesse selle puu peal pierud, siss nied pierud polesivad. A-ah, ilus oli [---] (ERA, CD 309 (33) < Olga Klaus, s 1922, ja Hustin Enkvist (Juhanson), s 1913).

Kuigi jaanipäevakombestikus oli palju sarnast, pidasid varem erinevad rahvusrühmad jaanipäeva eraldi: 
[---] Oo, no meil seda peeti, kogu üö tantsiti. A näe, sial üle tule hüppasivad ja keik. [---] Panivad teiva, teiva otsa misle vanad vierud leidsivad, siss valasivad tjökatit sinna ja panivad tule. Kogu üö põles. Neid oli pallu külas, lätlastel ossobenna, läti otsas [---] (ERA, CD 457 (23) < Selma Ignatovitš, s 1923).

Kalendrikombestiku uurija Mall Hiiemäe väitel pole teiba otsa tehtud jaanitule põletamine välistanud tuletegemist ka maa peale, sellest annab tunnistust üle tule hüppamise kombe populaarsus nii eestlastel kui ka teistel rahvastel (Hiiemäe 1985: 19).

Sestpeale, kui jaanipäevaürituste korraldamine jäi Rõžkovos kohalike kultuuritöötajate ülesandeks (klubi ehitati külla juba enne Teist maailmasõda, kuid palgaline kultuuritöötaja sai ametisse tõenäoliselt 1950. aastatel), hakati tegema suurt ühist jaanituld:

No nüit, kui juba kolhoosade aeg, siss juba keik ühes olivad, $i$ kluubas keik ühes käisivad ja [---] (ERA, CD 457 (23) < Selma Ignatovitš, s 1923).

Ühiseid pidusid soodustas ka lätlaste ja eestlaste kombestiku sarnasus ning keelelise identiteedi nõrgenemine.

Laulmine kuulunud nii virulaste kui ka lätlaste jaanipäevatraditsiooni. Ilmalike ja klubitraditsioonide rikastamise käigus 1970.-1980. aastatel korraldati kohaliku klubijuhataja eestvõttel lausa võistulaulmisi:

Igas uulitsas vai tänavas, kuida nüid ütelda, küsivad, et las iga uulits võstupajet. A siss lähvad kokku sinna, kes saab esimese koha, siss anneti, meil anneti kaks seda kasti piiva. A siss teised saivad puolteist, siss olivad vihased ja siss kes parembi, ühed kiitsivad üht ja teised teist ja.

- Et kes rohkem laulab siis või?

- Kellel ilusamad laulud, kes parembi [---] (ERA, CD 308 (7) < Emilia Naarits (Kodasma), s 1916).

Kodu-Eestis olid eri külade või külakooride võistlused enimtuntud õigeusklike setude aladel.

Rõžkovo virulased laulsid jaanipäeval ka näiteks läti laule. Lõuna-Eesti omaaegsete jaanilaulude viisid sarnanesid läti viisidega, kuid eestlaste vanem laulutraditsioon asendus 19. sajandi lõpul uuema lõppriimilise lauluga.

Liigolaule Rõžkovo virulased omaks ei pidanud, ehkki oskasid mõnevõrra neidki (liigolaulude kohta vt Latviešu tautas muzika 1973: 65-66). Läti jaanilaulude traditsioonis püsimisele aitas kindlasti kaasa 1980. aastate lõpupoole 
jaanipäeva paiku Rõžkovos käinud Läti delegatsioon, kes tõi külla uuemaid trükitud jaanilaulude kogumikke (nt Līgo dziesmas, 1989).

Jaanituli kui oli, sis nad siin ühe aasta olivad, sis andsivad neid raamatuid, kus sellest liigast on keiksugused laulud kirjutatud.

- Olid siis lätlased, jah?

- Jah. Igasuguseid neid liigalauluid.

- Aga kas neidsamasid liigalaulusid siis siin lauldi ka, mis seal olid kirjutatud?

- No iga laulu ei lauletud muidugi, meil ikka lausivad eluaeg liigalauluid jah. No sial on kovasti pallu neid laulusid, sis on mõni koguni erisugune, et meil ei ole teda millalgi lauletud, vot.

- Aga neid liigalaulusid teie ka oskasite või? Või ainult lätlased?

- No miks? Meie siin ku oleme, ühes elasime, ka oskasime, noh nendega laulsime ühes liigalauluid [---] Tolka lätiks (ERA, CD 449 (17) < Olga Klaus, s 1922).

Pühade-eelne majapidamise korrastamine on üldlevinud tava, aga Rõžkovo lätlaste traditsiooni kuulub eestlastele tundmatu jaaniöine perest peresse käimine, nn perede virkuse kontroll, millele võib paralleele leida eesti mardi- ja kadripäeva kombestikust. Hilisemal ajal on Rõžkovos virulasedki lätlaste kombes osalenud:

Enne käisivad, niiviisi enne käisivad, pääval juba vaatasivad, kellel ajad ei ole hiaste - see, kus oli roht vai mis ja, a mehedel, kui ovves oli pori vai ei old puhastatud ovve ja ei old, a metsast pidi tuvva koivu, nied panna veravatel juures. [---] Vot käisivad ja siss laul oli niukene, no vobšee, kui ütelda, jälle tarvis vene kielt. A prasmeivali. [---] Et sie peremies, perenaine on kovasti laisk, et ajad onvad keik rohu sies kasvatud. A kui peremehel ei old neid koivusi ja siin ei old keik ovves korjatud ära, et peremies on laisk kovasti.

- Aga see oli siis lauluga või?

- Lauluga, keik lauluga oli.

- A kes toda laulsid siis?

- A naisterahvas läksivad laulsivad. Oi, oli üks pikk laul lätiks [---] (ERA, CD 465 (19) < Poliina Sarantšuk (Blumfert), s 1927).

[---] Siis käisivad naised lauluga i keik nigu pilkasivad sind vai naersivad.

[---]

- See oli just lätlaste komme siis?

- Jaa. See oli lätlaste. 
- Aga kas nad käisid siis eestlaste õuesid ka vaatamas või ainult läti omasid?

- No meie olime ka artlis, milla nendega laulmas i käimas jah, a meie kielel ei old niuksi sonasid, a nendel oli niuksed sonad [---] (ERA, CD 460 (18) < Hustin Enkvist (Juhanson), s 1913).

Seega on Rõžkovo virulased mõnikord küll ühes lätlastega naabrite traditsioonis osalenud, kuid nad on teadlikud, et järgivad võõrast kombestikku.

Pererahvas, kelle juurde lauljad jõudsid, pidi omalt poolt külalistele midagi pakkuma, et sellega tulijate heasoovlikkus ja õnnistus ära teenida:

[---] No käisivad müöda talu, käisivad, laulsivad, a sie pidi olla olu ja kui sõr. Pidi jo, noh, hot' no pidi olla siss sel peremehel juba, perenaisel kovasti hiad onned ja luomadel.

- Siis käidi kohe peredes ja neile pakuti siis seda õlu?

- No tuppa tulivad ja laulsivad siis jo onned see lubasivad ja keik luomadele keigiti, no ras, no kui ugašali (ERA, CD 465 (21) < Poliina Sarantšuk (Blumfert), s 1927).

Õlle kui vana ohvrijoogi (vt Hndwb. IV, vg 733) joomine kuulub Kodu-Eestis veel tänapäevalgi jaanipäevakombestikku. Siberieestlastel pole õllepruulimine kuigivõrd juurdunud, sest seal ei kasvatata selleks sobivaid teravilju.

Jaanipäeva pühitsemist Jaani nimepäevana tunnevad mingil määral ka Rõžkovo virulased:

[---] Meil ka vanemb poeg Jaan, nii ta seda püha nii pidas, et. Tegivad, kel Jaanid olivad, sellel keikidel oli tehtud püha juba kodu. [---] No ohta, tiad, tulivad sial omad keik, kellel ehk viel oli Jaan, keik tulivad, jõivad ja olivad vähekene, siss läksivad tantsudel, tantsisivad ja. Enne ved ei old siukest ku nüid, et pallu joivad või juonud olivad või - seda ju ei old (ERA, CD 457 (23) < Selma Ignatovitš, s 1923).

Ometi pole Jaani nimepäeva pühitsemine Rõžkovos üldlevinud, nagu see on olnud mitmetes Omski oblasti algselt puhteesti külades (nt Zolotaja Niva, Semjonovka).

Veega kastmine, mis enamikes Siberi eesti külades venelastelt üle võetuna Siberi eestlaste jaanipäevatraditsiooni juurdunud (vt nt Korb 1998: 99), on Rõžkovo virulaste meelest võõras komme, mida on nähtud vaid naabruses asuvates vene külades. Ka tulevase ennustamist lillepärja vetteviskamisega peavad Rõžkovo virulased vene kombeks.

[---] Vene külades ei ole. Nendel on Ivan Kupala. Ivan Kupala, et pääval, kui on soe, nii nemad veega valavad ja tüdrukud siss lähvad joe juures 
vai sial siss tievad, no kui kruonud. Ja viskavad vie sisse ja zagadõvajut, et kui mehel minna [---] (ERA, CD 465 (23) < Poliina Sarantšuk (Blumfert), s 1927).

Vene vastavast traditsioonist on kirjutanud nt Vladimir Propp (2004: 76).

Jaanipäevakombestiku peamised elemendid - kodu ettevalmistamine pühadeks, haudade külastamine, jaanituli laulmise ja hiljem organiseeritud isetegevusega on elav, tänasel päeval erinevaid rahvaid ühendav püha. Siiski on säilitatud oma identiteet - eristatakse oma ja võõrast kombestikku ning erinevalt paljudest teistest Siberi piirkondadest ei ole eriti üle võetud tänase dominantrahva vanemaid kombeid.

\section{Lihavõtted}

Lihavõttepühi nimetavad Rõžkovo virulased nagu teisedki Siberi eestlased enamasti munapühadeks, sest munade värvimine, kinkimine ja söömine on olnud nende pühade juurde kuuluv levinum tava paljudes Euroopa maades. Rõžkovos on tuntud nimetused veel soome keelest tuletatud päässet (vrd sm pääsiäinen) ja vene keelest tuletatud paska (vrd vn nacxa).

Paljudel rahvastel, ka eestlastel ja idaslaavlastel on lihavõttepühad lähtunud eelkristlikest kevade vastuvõtmise ja tervitamise traditsioonidest, see on ka noorte kevadise kooskäimise algusaeg (Hiiemäe 1981: 238; Sokolov 1941: 149). Lihavõtted on Siberi eestlastel üldiselt ja ka Rõžkovos tähtsaim kevadine püha. Lihavõtteaegset kiikumist, mis Kodu-Eestis tuntud põhiliselt Lõuna-Eesti alal (Hiiemäe 1981: 238), enamikes Siberi eestlaste külades tänapäeval ei tunta, Rõžkovos on see aga olnud üsna populaarne, ilmselt ka soome traditsiooni toel (vt Talve 1961: 15):

Lihavetteks meil tehti suured kiigud, kuvve käispuuga. Siss sial kiigul seisime ja istusime ja siss laulsime neid pikkaid lauluid keik [---] (ERA, CD 461 (6) < Emilia Naarits (Kodasma), s 1916).

Kaugesse minevikku ulatuv munade värvimise komme (Fehrle 1955: 128129) on Rõžkovoski hästi tuntud. Tavalisim on läbi aegade olnud munavärvimine sibulakoortega. Tööstuslikke munavärve, mida enamasti kohalikust kaubandusest saada ei õnnestunud, on virulased hankinud Eestis elavate sugulaste-tuttavate kaudu, viimasel aastakümnel ka Saksamaale ümberasunud külaelanikelt.

Mune oli kombeks kinkida ristilastele, mõnes paigas ka lihtsalt tervitamas käijatele (Hiiemäe 1981: 240; Beitl \& Erich 1955: 586; Dal 1957: 903). 
Anu Korb

Siberieestlastel, sealhulgas ka Rõžkovo virulastel, on tavaks olnud, et ristilapsed käivad ise ristivanematelt mune ja maiustusi küsimas, nagu see on tavaline vene kombestikus (Zolotova 2005: 60). Osa lapsi leidis sel päeval kohase olevat mitte ainult ristivanemaid, vaid ka teisi külaelanikke väisata. Perenaised valmistusid spetsiaalselt laste vastuvõtuks ja nooremate ristilaste külastamiseks:

[---] Mul oli kakskümmend neli neid ristilapseid. [---] Jah, ja siis, ku see püha tuli, no siis ju kah pahasti hot' elasime, siis ma korjasi neid munasi ja siss vähekene ostsin neid kompvetid. [---] A mõnikesed tulivad $i$ ilmagi, ilma, a ristilapsed, nied tulivad, siss jo ma nendele andsin vähekene rohkem, a kes tulivad niuksed: Kristos voskres, tak, podaite krasnuju jaitsu! Tak, siss ma andsin ühe muna ja seal vähekene konfetit [---] (ERA, CD 455 (25) < Mari Streit, s 1921).

Suuremad lapsed, kes kodukülas mööda peresid käimist häbenesid, võtsid lihavõttepühade ajal sageli ette teekonna mõnda lähedal asuvasse vene külla:

[---] Lihavetted ku olivad, siis ma läksin oma padrugaga Kolotsasse, vot kaks kilomeetrat siit. Omas külas oli häbi. Läksime sinna kerjama, ja just no pühad olivad. Siis meil sial anneti kanamunasi ja strääbanid anneti ja leiba anneti, kartuli ei annetud, a neid anneti, nigu püha oli. Me nii hiameelega tulime kodu, nii lõime laulu müöda tied, nii et jumal hoidku!

- Te olite lapsed siis või?

- Noh, lapsukene viel olin, no muidugi. [---] A padruška elas mammaga ja isaga, nendel oli süia ja keike oli ja ta ütleb, et lähme teise külasse, sial saame palju munasi ja mis annavad, strääbanid või miski annavad. Ja't nii oligi [---] (ERA, CD 475 (1) < Helena Bertis (Matvejeva), s 1933, ja Ann Klaus (Štelmahler), s 1925).

Laste jaoks olid lihavõttepühad muidugi eriti põnev ja oodatud aeg:

A siss ku lihavetted olivad, siss jooksivad muna järgi. Isi läksivad, no väiksel kummi isi toi, a ku suuremaks saivad, nii ooi, nad üösse ei magand. A nii oli voetud juba see asi: lihavetted, lihavetted, ommiku juba: Ema aja mind vara üleval, lihavetted, vaja minna. No lähvad. A vot see iestiks ma ei tia, käivad, on Iestimaal nisukest, et käivad selle muna järgi lapsed vai ei ei ole.

- Ei ole.

- Vot nad a see, mis lähed tuppa ja: Hristos voskres, see nagu vene, vot. See nii, nigu see abõtšie on vene. 
- Nii et laps läheb muna järgi, siis ütleb niimoodi või?

- Ja läheb tuppa, ütleb: Tere. Kristos voskres, Kristos voskres, Kristos voskres! Kolm korda i: - Voistenno voskres! - Vot i siss annad talle. [---] (ERA, CD 476 (3) < Helena Jurjeva (Madis), s 1927).

Nagu eelnevatest tekstidest nähtub, on Rõžkovos, nagu mitmetes Siberi eesti külades (vt Hiiemäe 1998: 113), venelaste õigeusukultuurist otselaenuna tänaseks üle võetud ka lihavõttepühadeaegne tervitus. Eestis, setu alal käisid lapsed vastava salmiga tervitamas jõulude ajal.

Kui mõnel pool Siberi eesti külades ei kannatanud lihavõttepühad eriti ideoloogilise surve all (vt Hiiemäe 1998: 115), siis Rõžkovos keelati alates 1920.1930. aastatest koolilastel isegi munapühadeaegne ristivanemate külastamine. Seetõttu traditsioon küll ei kadunud, kuid teisenes - ristivanemad hakkasid ise oma ristilapsi kingitustega (värvitud munad, küpsetised, maiustused) külastama. Lähemate sugulaste juures jätkus siiski ka traditsiooniline munakorjamine:

Ma ikka ütlesin, a siis oli nii, et kuolilaps ei tohtind käia ja ei annetud, nigu ei usutud seda.

- Koolist ei lubatud, jah?

- Ei lubatud, et ei, lihavett on jumala püha, ei lubatud. Ma ütlen, siit tulete omal vanaemal ja keski miskigi ei tia. Ja tulge. A mina siis keik omadel lastel keik tien nisukesed pagetid, keikidel nendel ostan lihavetteks kogu aeg. Las ta viel on vaikku kiigus, sie laps, aga mina oma osa keikidel andsin [---] (ERA, CD 476 (3) < Helena Jurjeva (Madis), s 1927).

Eestis oli 19. sajandi lõpu ja 20. sajandi algupoole lihavõttepühade oluline tunnus, et noored mehed käisid küla peredest mune korjamas, nõukogude ajal värviti ja vahetati mune kodus ja sugulaste vahel, setu alal säilis aga noorte meeste munamäng, nn munaveeretamine (vt nt BERTA 2004).

Nõukogude Liidu lagunemise järgselt on usk ja kirik Venemaal jälle au sisse tõstetud. Keelatud pühi enam ei ole ja munakorjamine saab aina uut hoogu juurde:

Enne jo käisivad lapsed. [---] Üksvahe ei lasnuvad kuolist, rääkisivad, kesle käis krestovaitama. - Tänavaasta mul niipallu käisivad, et mul ei tabandki. - No tänavaasta, nüit ju voivad käia, enne ju ei ehtind... Ma kakskümmend muna kietsin ja värvisin ja mis kompvetkaid ostsin ja mul ei taband. Isi hot' oleksin ühe mekkind. [---] Ja siss viel strääpasin, andsin kellele kringli ja kellele mis, niiviisi paarita ikke. Ühte ei, a paaret anda. [---] No see on zakon, et nigu paarita anda. [---] Üht ju et anna. Siis nendel on nii hia miel, ku lähvad, et ei tiagi: et 
vaata, eta babuška. [---] Ja nii rehelised lapsed on. Tiad, kuda nibut' lapstel vaja ju on, kerd nende päev on ja. Siis kogu pääv nad joosevad [---] (ERA, CD 464 (13) < Emilia Jurjeva, s 1919, ja Pauliina Mattova, s 1921).

Lihavõttepühade dominandiks on jäänud munade värvimine ja kinkimine, õigeusu kultuurist on virulaste traditsiooni kinnistunud ka vastav pühadetervitus.

\section{Suvisted ehk nelipühad}

Suvisted kuuluvad aasta kesksete rahva- ja kirikupühade hulka. Rahvakalendris on need olnud meeleolukad kaselõhnased pühad.

Nimetust suvisted või suvistepühad Rõžkovos ei tunta. Pühade nimetusena on üldlevinud kirikukalendris tuntud nelipühad või venelaste eeskujul trooitsad (vrd vn mроииа). Nelipühade nimetust on seletatud mitmeti: 1) need on kehtestatud 1696. aastal neljandate suurte aastapühadena peale jõulude, lihavõtete ja jaanipäeva; 2) tegemist on neli päeva kestvate pühadega (Hiiemäe 1984: 209, Eisen 1920: 151). Rõžkovo virulased toetavad teist seletust:

[---] Nelipühid me pidasime ikka nellal pühal. Raamatus ma loen, iesti raamatus on aga kaks püha, kirikupühad, a meil neli püha pidasime [---] (ERA, CD 451 (33) < Emilia Naarits (Kodasma), s 1916).

Kodu-Eestis olid suvisted sisuliselt suve vastuvõtu pühad, kus pearõhk oli noorte kooskäimistel ja kodu kaunistamisel (Hiiemäe 1984: 209), sama võib öelda ka Rõžkovo eestlaste kohta. Suvistepühadest algas Rõžkovos küla lähedases metsas tantsimas käimine. Üheskoos tantsuplatsile minek oli osa suvistepäeva pidustustest. Suvistepüha tantsudel ja lõkke tegemisel osalesid ka lapsed, mis Siberis noorte kooskäimistel üldjuhul tavaks polnud:

Jälle me ütlesime troitsad, nelipühist hakkas piale. Siis metsas meil olivad tantsud, siinpuol olid, ei ole ka kaugel. Ka lätlastel olid sinnapuole vähekene, meil siiapuole. Poisid läksivad pilliga, nuh, esimestes metsades läksivad pilliga, a siis tüdrukud ja siis naised ja lapsed, siis lapsed tegivad, korjasivad sial, tuld tegivad ja kastjor vai ku venelased viel ütlevad.

- Nii et sinna võisid lapsed ka minna, jah?

- Keik võisivad minna. Tuli ku sie, kui ütelda gul'atasivad vai sõitsivad hobustega, pillidega käidi ja kes kui tahtis. [---] Niikavva kui jaanipäevast saadik käisime metsas tantsidel (ERA, CD 451 (33) < Emilia Naarits (Kodasma), s 1916). 
Kodu-Eestis on suvistepühal surnuaial käimine eriti populaarne ortodokssete setude juures (vt Hiiemäe 1984: 216-217), õigeusklikel ongi see oluline esivanemate mälestamise päev. Siberieestlased, sealhulgas rõžkovolased, on aga üsna üldiselt suvistepühaaegse esivanemate mälestamise venelastelt üle võtnud.

Seega on Rõžkovo virulaste suvistepüha traditsioonis olnud olulisel kohal nii lõbutsemine - ühiselt metsa minek, seal tantsimine ja tuletegemine - kui ka esivanemate mälestamine.

\section{Vanemate mälestuspäev}

Pärast Teist maailmasõda, kui segaabielud järjest sagedamaks muutusid, on Rõžkovo virulased hakanud tähistama ka vanemate mälestuspäeva raditelskit (vn радуница), mis leiab aset teisel teisipäeval pärast lihavõttenädalat (vt Zolotova 2005: 63) ja on tänapäeval Venemaal töövaba päev:

[---] Ja tuleb trooitsad, siss surnuaial käivad. [---] Meil on roditelski den', vanade püha vai kui ütelda. [---] Me eluaeg ei pidand. Troitsat pidasime, et trooitsaks no läksid sinna, mis nii viisid nigu ja sial raamatud jumala lueti ja ja no jumalapidu piati sial ja istusivad sial vanad ja surnuajal käisivad, surnuaed oli täis. [---] Kui siia venelased tulivad, nüit on meil näe, nii kõvasti piavad seda roditelski den'. [---] No mul tulevad poisid, tal vene naised on, nad lähvad surnuajal, no $i$ viivad mind ka. [---] Poisid piavad nüid nigu vene viisi. [---] Ta meil on kalendaaris see kohe kirjutatud, raditelski den' miuksel pääval [---] (ERA, CD 476 (4) < Helena Jurjeva (Madis), s 1927).

Nüüdseks on naabritest-sugulastest venelaste eeskujul üldiseks saanud ka surnuaiale söögi-joogi kaasavõtmine (vt Propp 2004: 23), kusjuures osa kaasavõetust jagatakse lahkunud omastega, valades hauale alkoholi ja puistades sinna toitu:

[---] Surnuajal meil käivad troitsadeks, kui jaanipäevaks ja siss, kui ütelda nüit, roditelsko pääva, siss käivad sumkadega keik sial, ugašoitavad neid surnuid. [---] Sinna haudade pial munasi raputame, no komvetid, präänikuid raputame et, ja kes siis istuvad ja stopkat juome veel sial [---] (ERA, CD 456 (1) < Mari Streit, s 1921).

Seesugune komme oli varem laiemalt levinud ka Eestis, kuid säilis elavana pärast Teist maailmasõda õigeusualadel, kus kalmistule viiakse toitu külapühal. 


\section{Mardi-ja kadripäev}

Nii mardi- kui kadripäev on Eestis tänini elavad rahvakalendri tähtpäevad, kombestiku juurde kuulub maskeeritult perest-peresse käimine ning pillimängu ja laulu saatel andide kogumine. Olemuselt on mardi- ja kadripäevakombestik üsna sarnane, põhierinevuseks on santide välimus - kui mardisandid on taotluslikult mustad ja rohmakad, siis kadrid püüavad end võimalikult ehtida, riietudes heledatesse naiseriietesse.

Erinevalt emamaast on mardi- ja kadrisandis käimise komme Rõžkovos tänaseks hääbunud ning martidel ja kadridel vahet ei tehta. Minevikust on elanike mälus säilinud teadmine, et sandid pidid end võimalikult hästi maskeerima:

[---] Panin, kes kui oskas, pani enda pahempidi kasuka selga või miski, kes määris silmad tahmaga, kes pani selle kardina ette või kui, et silmad eivad tunne, kes on (ERA, CD 453 (23) < Emilia Naarits (Kodasma), s 1916).

Mardi- ja kadrisantide erinevast riietusest, nt valgetest ilusatest kadridest, mis Kodu-Eestis ja mujal Siberi eestlaste juures üsna tuntud, Rõžkovost teateid pole. Eelkõige mäletatakse praegu kombestiku meelelahutuslikku poolt:

[---] No ukse takka läksime, siss, kui ütelda, mõnel oli balalaika käes, et tuas lubatud, küsis luba mängida, et tantsisivad. Mõni oskas kätt vaadata, vorožoitas vai miski niukest [---] (ERA, CD 453 (23) < Emilia Naarits (Kodasma), s 1916).

20. sajandi algupoolel oli Rõžkovos sandis käimine ilmselt üsna populaarne:

[---] Vahest käisivad viis-kuus parti, ku hakkasivad käima. Siss, ku lapsed olivad veiksed, siss, no ma sain tüdruku piast, aga naise piast ma enamb ei saand kuhugi käia [---] (ERA, CD 458 (5) < Selma Ignatovitš, s 1913).

Vähemalt hilisemal ajal olnud mardi-ja kadrisandiks käimine põhiliselt laste ja noorte lõbu:

Enne meil oli niuksed, mardipäe oli ja katrina päe, kadrinapäe oli, siss laulsivad i siss ja käisivad, me isi, tüdrukesed, käisime kerjamas [---] (ERA, CD 466 (20) < Emilia Ignatovitš (Sommer), s 1929).

Mall Hiiemäe täheldab, et sanditamiskombe muutumisega meelelahutuslikuks ettevõtmiseks on sandiskäijate iga noorenenud (Hiiemäe 1994: 17). Siiski osalenud Rõžkovos sandis käimisel ka abieluinimesed: 
[---] Lapsed käisivad eri ja vanemad eri, kes tahtis aga.

- Aga kas sa siis võisid abielus ka olla või pidid üksik olema, kui käisid? - A olivad naised kah. Kelle mies lubas oma naist. Igaüks ei luba ved. [-

--] (ERA, CD 453 (23) < Emilia Naarits (Kodasma), s 1916).

Traditsioonilises külakogukonnas ongi olnud meestel enam vabadust ja otsustusõigus ning naistele kehtivad märksa rangemad moraalinormid (vt Korb 2005: 90-91). Kombestiku alalhoidmine on aga Siberis väga tugevasti naiste õlul.

Andide kogumine, mis mitmetel rahvastel enam talvise pööripäeva ümbrusse koondub, kuulub Eesti traditsioonis just mardi- ja kadripäevakombestikku (Hiiemäe 1994: 23). Mardi- ja kadrirituaalil oli kindel ülesehitus: sissepalumislaul ukse taga, toas tantsimine-laulmine, pererahva virkuse kontroll, annete mangumine, andide saamine ning tänu- ja hüvastijätulaul.

Rõžkovo virulasedki mäletavad, et sandid lasti enamasti ikka sisse ja neile anti söögipoolist:

Tantsisivad ja laulsivad ja küsisivad keikid: Anna, anna lihapurukest, anna jahutolmukest, anna piimatilgakest [naerab], anna kanamunakest. No keiki küsivad, mis ju oli, seda andsid siss. Pidi anda. Siss suovisivad hiad onned keikid ja.

- Nii et neile alati anti ja lasti sisse alati?

- Jaa, kui laulsivad ukse taga hiasti, siss lasivad sisse, siss andsid ja läksivad ära, tänu andsivad: Anna jumal, annaks teil prigonasse hiad luomaonne ja tuppa lapsionne ja...

[---] Mardid sandid laske tuppa, mart on tulnud kaugelt maalt üle mere, üle suo, üle pika pilliruo.

Mardi varvad valutavad, külmetavad, mardi kü̈̈ned valutavad.

Pai pereemake, pai pereisakene, laske tuppa!

Nii nad seda ka laulsivad [---] (ERA, CD 458 (5) < Selma Ignatovitš, s 1923).

Mõnes Rõžkovo peres jäeti sandid ukse taha. Sajatussõnadest on seal meie päevini säilinud just karjakasvatuse kui tähtsaima elatusalaga seonduvad:

Kes ei andand midagi, tuppa last, sellel siis [---] ütlevad: "Saaks teil miski hundid lambad süoma." Lubasivad rumati ja. A siis aeti neid piitsaga järel ja keiki oli [---] (ERA, CD 453 (23) < Emilia Naarits (Kodasma), s 1916). 
Anu Korb

Kodu-Eesti santide sajatused on talletatud muidugi mitmekesisemana, kuid karjakasvatusega seonduvaid on nendegi hulgas rohkesti (vt Hiiemäe 1994: 105-106). Sajatustesse tõsimeelse suhtumise tõenduseks on nii Eestis kui ka Siberis, sealhulgas ka Rõžkovos, levinud vastavasisulised õpetlikud lood:

Siin oli üks vanamuor, ta ei laskend tuppa. Noja, a nied tüdrukud oli läinuvad, see, juba ka enne Idad, Idaks kutsuti vanamuor, ei ole laskend, no i siis nema, nied tüdrukud olid, et annaks teil, et hunt murraks lammad. I temal murdki. Hunt oli teisel aastal murdand selle lamma. No nüit teisel aastal, kui tuli sie püha aeg, nii vanamuor juba värava taga daže uotab, et tule, ma teil keiki anname, tulge nüid, tüdrukud, vot. A nemad prosta niisama, et saaks hunt selle. A kuule, temal hunt oli reibindki selle lamma. No ta teisel aastal juba keik kutsub tuppa: "Tulge, ma annan keiki teil." No mis sa tied (ERA, CD 462 (24) < Miilja Kasak, s 1926).

19. sajandi lõpus ja 20. sajandi alguses peeti Eestis kogutud andidega mardivõi kadripidu. Algselt oli komme rohkem levinud Lääne-Eestis. Suuremat pidu pidasid täisealised noored, kuid andide ühine jagamine oli kõikjal tuntud.

Sanditamisele järgnenud päeva õhtul peeti Rõžkovoski mõnes lahkemas külaperes sandipidu, kusjuures kirjutamata tavaks oli, et osalised katavad peoga seotud kulud ja koristavad ruumid:

[---] A teisel pääval, siss juba ohta, kui süöki sie lavva taga sööme, siss balalaikad mängisivad ja too oli sie taljanka, siss ju pillid ei old viel. Siss meil niuksed veiksed adnorjadki bõli niuksed. Tantsisime ja. Oli illus, vesjöl oli. [---]

No siss lopetasime nied tantsud ara keik, kes juba perenaine, lasi meid nigu keik sial nied seda lavva pidasime, nendel viel puid saagisime, poisid saagisivad puid, lohkusivad sial rankusi sial, a tüdrukesed ohta siss juba läksivad ara, pesivad porandad ara, porandad puhtad jätsivad, et las ta omiku perenaine hakkab üles, et porand oles puhas old. Riistaid pesime ara i porandad pesime $i$. [---] Siss jo nied seda elektrot ka ei old. Lambi karassiinat toime, karassiinat kodust toime i las perenaist nigu me emme ne abežali. [---] Meil oli vot meie otsas siin, Orlova ots kutsusivad seda, see Orlova ots. Vanamies vanamehega, nad olivad juba vanad. Nendel ju omasi lapsi ei old, a sie vanamuor ja vanamies, nad nii head inimesed olivad, nad iga kord kutsusivad i meid. [---] (ERA, CD 466 (20) < Emilia Ignatovitš (Sommer), s 1929). 
1930. aastate repressioonide perioodil hääbus Rõžkovos sandiskäimine suuresti. Aeg oli meelelahutusteks ärev ja võimud käsitlesid mardi- ja kadrisandis käimist kui nõukogude inimesele sobimatut kerjamist:

[---] Perast kielati ära, perast ei lastud.

- Ja mis ajal see ära keelamine oli umbes?

- No see oli rohkemb vot 37 ndal ja vot siukstel aastatel, kaheksandal ja siss ei käidud kuskilgi keski miski. Vot oli see suur see, kuda ütelda, repressia või mis ta, hakkasivad neid arestovat neid mehi siit, üösseti käidi, tulivad tuppa i. Siss enamb ei lastud. [---] A piale sõja, siss jälle vähe aega omas külas tiad, et ei old siukest [---] (ERA, CD 458 (5) < Selma Ignatovitš, s 1923).

Venemaal on eesti rahvakommete täitmisele nii mõnigi kord takistuseks saanud ka traditsiooni mitte tundvad vene ametnikud:

Meil oli üks polnomotšias siin. Meil läksivad kerjama naised, kadri vai mart, mis ta oli, mina panin neid riidesse. Ja üks meesterahvas oli kah nendega. Läksivad kohe üle tie siia Ivanovadele. No seal laulsivad ukse taga, lasti tuppa. A küsisivad mis, sial andis perenaine. Nemad, kui ära läksivad, see polnomotšia nendel järele. Kuhu nemad lähvad-järele. Läksivad teise kohta - a tema õvves sial. Tulivad teisest majast, tulivad välla sial - tema kallale nendele, sellele meesterahvale, raputas rinnast ja: "Miks te käite kerjamas, kuhu see kõlbab?" [---] (ERA, CD 307 (32) < Emilia Naarits (Kodasma), s 1916, ja Maria Vedom (Kodasma), s 1913).

Eriti püüti mõjutada noori, et nad vanad "iganenud" kombed kõrvale jätaksid. Rõžkovost on teateid ka vastavate survemeetmete kasutuselevõtust:

[---] Ma mardisandi iest sain nurkas viel seista. Muidu olin hia õpilane, kuolis ku käisin viel, ei tea, mitu aastat mul oli. No a kord ma olin, armastasin keike nalla, mul vaja minna, kaks tüdruket meid, teised olid poisiksed, juoksime, koos školnikud keik, juoksime mardisant. A saadi, õpetaja küsis, siss ei old luba joosta, õpetaja küsis, kes käis. Pidi tunnistada. Siis küll oli, kui ütelda, hale seista nurkas, et häbi teistest ka, et millalgi ma seda ei tienind, a siis martide perast täidis nurkas seista [---] (ERA, CD 453 (23) < Emilia Naarits (Kodasma), s 1916).

Mardi- ja kadrisandis-käimine Rõžkovos 1937. aastaga küll päriselt ei lõppenud, kuid kombe keelustamine võimude poolt aitas tava taandumisele kindlasti kaasa. 


\section{Igrištše-traditsioon}

Rõžkovo virulased on venelastelt ühes vene laulude-tantsudega võtnud üle nn igrištše-traditsiooni, mis oli tuntud ka Omski oblasti Kovaljovos (Viikberg \& Vaba 1984: 215), kuid enamikus Siberi eesti külades pole tava juurdunud. Idaslaavlastel on igrištše eelkristlike pidustuste nimetus, tänapäeval on termin kinnistunud laule, tantse, maskeerimist, mänge, mõistatamist jms hõlmavatele pidustustele, mis kuulusid kalendritavandisse, eelkõige lihavõttetavandisse (Kabašnikov et al. 1993: 90-91). Rõžkovo kohapealse nimetusega igrõšad olid noorte kooskäimised, mis kestsid külas mardipäevast vastlapäevani. Seal lauldi vaid vene laule ning tantsiti vene tantse. Paralleelsed nähtused Eestis olid 17.-18. sajandi mängutoad ja hilisem videviku pidamine.

Õigeusklike paast mõjutas Rõžkovos ka luteriusuliste käitumist: nad ei paastunud, kuid tantsimine ja lõbutsemine oli sel ajal rangelt keelatud.

[---] Enne jouluid juba käisivad igrõšatel ja no kesnibut' laskis talus, siss tantsisivad siss ohta, tüdrukesed pesivad porandad, poisid sial kasisivad vällas, et ei olnd miski jälle peremehel.

- Mis ajast need igrõšad hakkasid siis?

- A po mojemu mardipäävast. [---] Vot siss joulust saadik iga ohta käisivad: joulud käisivad, siss joulust jälle tantsisivad nii kavva, kunis tuli see, mh, kuda teda ütelda, paast tuli, maslenkast saadik. A maslenkast, siss juba, nä̈̈, hakkas paast lihavettedest saadik. Siss ei käidud tantsimas ja ja punaseid riideid selga eivad pant, rohkem mustadest riietes.

- A teil eestlased ka paastusid või?

- Eivad lauland ja eivad tantsind. A niiviisi, et süögi puolest, kui näed venelased, seda meil ei old. Me sõime nii kui sõime, nii sõime. A venelased, näe, nad siss liha eivad süönd, piima eivad süönd, a meil seda ei olnd. Meil aga eivad lasknuvad tantsida ei laulda, vot selle paastu aeg [---]

- Aga mis ajast siis uuesti tantsida võis?

- A siss lihavettidest [---]

- Aga kui need siin külas olid need igrõšad, sinna lasti lapsi või?

- A sii suurtega ei, me suurtega emme käind. Meil olivad kodu jälle omad veikstega igrõšad. [---] Äia siss meid juba korjas keik ära ja siss laskis sial kümme-üksteist last, kaksteist, naabrilapsed. Ja siss sial ta oli meil ülemb, siss meil olivad omad igrõšad: siss tantsisime ja laulsime nii et et [---] (ERA, CD 457 (25) < Selma Ignatovitš, s 1923). 


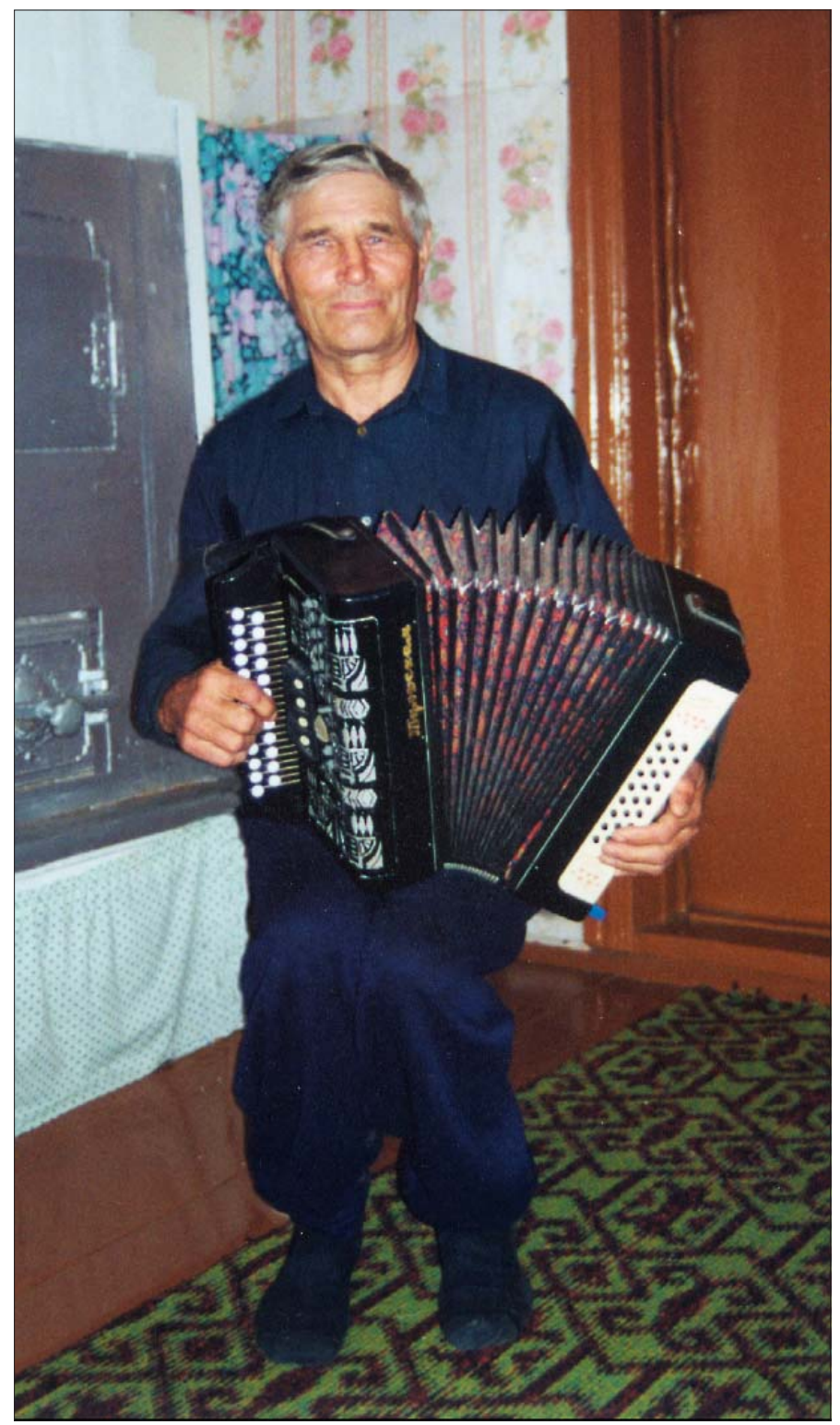

Foto 3. Nikolai Krizo (Kriisa Kolja) on üks viimastest külapillimeestest. Anu Korbi foto 2000 (ERA, VF 3283).

Igrištše-traditsioon hakkas Rõžkovos taanduma sestpeale, kui noorte kooskäimiseks asutati külaklubi, mis pakkus tantsuõhtute kõrvale ka ajakohasemat meelelahutust (nt kino, professionaalsed esinejad jm). 


\section{Jõulud, aastavahetus ja kolmekuningapäev}

Jõulud ja aastavahetus on kõikjal maailmas püha, mida tähistatakse vanadest tavadest lähtudes rohkete toitude, mängude, laulude ja lõbutsemisega. Jõulud, mille juurde kuuluvad erilised toidud, kuusk ja kingitused, sageli ka kirikuskäimine ja küünalde süütamine esivanemate kalmudel, on tänapäeva KoduEestis siiski olulisemal kohal ning aastavahetusest kodukesksem. Kolmekuningapäev tähistab jõulutsükli lõppu.

Kolmekuningapäeva ja jõulude paralleelnimetused on Rõžkovo virulastel venekeelsed, nagu üldiselt teistelgi Siberi eestlastel - kreštšenje (vene k $k p e$ ищение), roždestvo (vene $\mathrm{k}$ рождество).

Jõuludest räägitakse Rõžkovoski kui suurtest pühadest, mil tähtsal kohal olid ka pühadetoidud:

[---] Kui joulud olivad uodata, siis tehti-vorstid tehti ja pilmenid tehti ja keikesugust trä̈̈pamist trääbati, keikesugused kuokid tehti. Kakku ja piirakaid - siis oli nii pallu teda valmis, et kogo pühadetegu oli valmistetud [---] (ERA, CD 451 (2) < Mari Blumfert (Särg), s 1922).

Nagu eelnevast loetelust nähtub, on rõžkovolaste jõulutoitude hulgas nii Eestis tuntud traditsioonilisi pühadetoite (nt vorstid, kook, pirukad) kui ka vene omi (nt pelmeenid). Jõuluöö, samuti nagu vana-aastaõhtu ja -öö ohtrast söömisest loodeti järgmiseks aastaks rikkalikku söögilauda (Hiiemäe 1995: 61).

Varemalt oli Rõžkovoski kombeks jõululaupäeval ja jõulu esimesel pühal kirikus käia:

Siss hommiku hakati üles. Vällas, mis oli teha, tehti. Enam miski süöki ei laetud, keik oli valmis. Vara, vara minti kirikusse. Pime oli, kogoni pime, kui minti kirikusse. Kellad helisivad, kirikus oli kell. Kolm korda lüödi kella. Esimene kord tehti kirikud lahti, lüödi, teine kord lüödi, a kolmas kord, siss jo hakkab teenistus. Esimene kord lüödi nii harvapomm-pomm-pomm, teine kord viel tihtimbi, a siis ju, ku hakkab tienistus: pim-pom, pim-pom, pim-pom - niiviisi (ERA, CD $451(3)<$ Mari Blumfert (Särg), s 1922).

Kiriku sulgemise järgselt pidi komme muidugi taanduma ja osalt asendus see koduse jumalasõna lugemisega.

Jõulupühad olid ka külaskäimise ning pidude aeg, kuid erinevalt KoduEesti traditsioonist, kus jõululaupäeva õhtupoolikul ja jõulu esimesel pühal üldiselt külas ei käidud (vt Hiiemäe 1995: 67), sobisid Rõžkovos külas- ja peolkäiguks kõik jõulupühad: 
[---] Peati, neli püha oli jouluid. [---] Sedmova janvarja do desjatovo.

- Ja mis siis tehakse tollel jõulupühal?

- No mis, no vanad inimesed nüid käivad, tšaiut juovad, a nuored mis tievad, ei miskigi. A me, kui läheme üksteisel, tuleb kes gosti, paneme $i$ tšaiut pia laua pial juome. A nüit ei käigi neid liiga. Enne kuda nie vanamuorid käisivad, a nüid nied vanamuoridki ei ole, üksteisel harva käivad. A enne ju oli, vanamuorid saberutsa v adin dom, tšaijujut, sidjat, razgavarivajut, apjat tšaijujut.

- Kas esimesest pühast peale käidi juba või?

- Jaa, esimesel pühal jaa. Esimesel pühal keik.

- Aga mis lapsed jõulude ajal tegid vanast?

- A mis, ku olivad ju nastojašad plikad, käisivad tantsudel, igrišed misle olivad.

- Seal käisid lapsed ka või?

- No lapsed veiksed ei käind, a tüdrukud, tüdrukud, poisid, kluuba ei old, a käisivad igrišad, talus vot oli primer tantsud, igrišad kutsuti. A kluubasid siss ei old, ku ma mäletan, a ma olin niukene. Mul endal vanemb ode käis igrišatel. [---] Ma ei saand igrišatel käia. Meie aeg enamb ei old. Me kui saime plikaks, siss olivad juba kluubad [---] (ERA, CD $462(20)<$ Miilja Kasak, s 1926).

Ainuke Gregoriuse ehk uue kalendri järgi tähistatav püha Rõžkovo virulastel on aastavahetus: 1. jaanuarist algab uus aasta ka Venemaal. Mall Hiiemäe (1999: 16) märgib, et vana-aasta traditsioonide kõige olulisem tunnusjoon on rõhuasetus inimsaatusele, inimese tulevase käekäigu ennustamisele. Rõžkovo virulaste aastavahetusekombestikus on ennustamine tähtsamal kohal kui paljudes Siberi eesti asundustes. Mingil määral on Rõžkovos ennustamine seotud ka kolmekuningapäeva ja jõululaupäevaga. Ennustamisviise teatakse Rõžkovos üsna rohkesti, võimalik, et traditsioon on paremini püsinud just kohalike venelaste toel. Mall Hiiemäe (1998: 122) hinnangul on idaslaavi rahvastel ennustamised kauemini populaarsena püsinud. Venelaste eeskujul kasutatakse ennustamise kohta enamasti venekeelset väljendit vorožaitama (vrd vn Ворожить).

Rõžkovo virulaste andmetel on ennustamine olnud eelkõige neidude pärusmaa ja põhiosa tänini meeles püsinud ennustamisviisidest on seotud meheleminekuga.

[---] Tuli see uus aasta, siss vorožoitasime. Kuhu puole, kus see onn on. Votsid pimmi jalast ja läksid välla, viskasid üle värava: kuhu puole läks pimmi sie ots, siss sinna läksid mehele [---] (ERA, CD 460 (13) < Hustin Enkvist (Juhanson), s 1913). 


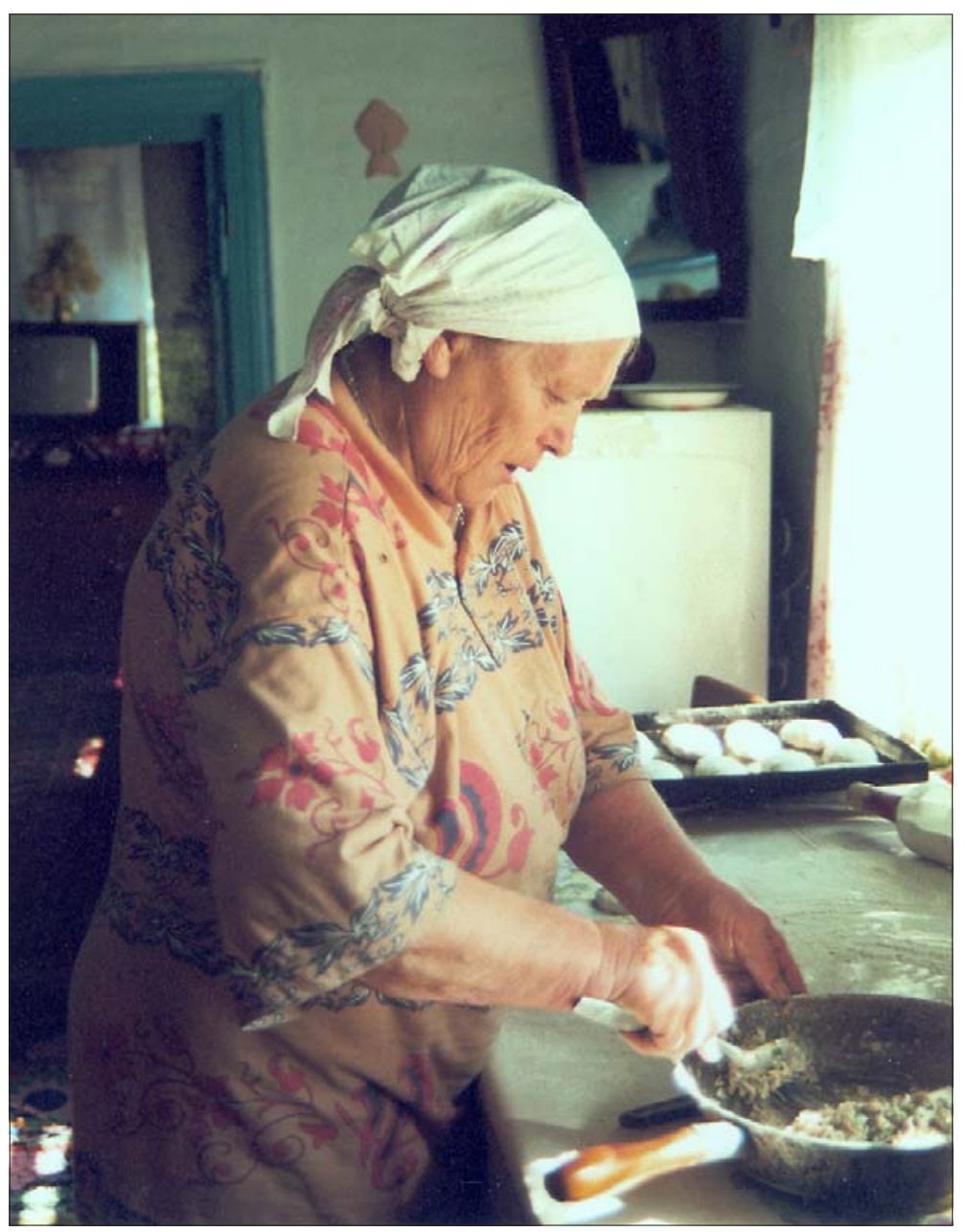

Foto 4. Helena Jurjeva küpsetab pühadeks pirukaid. Anu Korbi foto 2000 (ERA, VF 3242).

[---] Vot lähed, silmaid sidusid kinni, sidusivad kinni ja siss müöda tied läksime. Kuhu puole lähäd, sialt sis sul lieneb sie peigmies. [---] Ah, see jutt oli. Keik ta oli vale [---] (ERA, CD 472 (4) < Mari Streit, s 1921).

Mismoodi neid puid toodi?

- A puid votame: ku paariti, siss lähed mehele, kui ei ole paariti, siss et lähe mehele ja.

- Nii et võtad lihtsalt ja siis toas loed ära?

- Noh, votad nii, kohe äkisti votad, ei vota ju boletška haavalt, a votad, et nii kohe äkisti ja tuod, viskad tuppa. No ku vaatad-aa, on paar, a-ah 
paaril ei ole, naerame jälle isi. No mis tied. Miskid et tie. Vot (ERA, CD 462 (21) < Miilja Kasak, s 1926).

Ennustamised kinga vm jalanõu viskamise või halgude riidast tuppatoomisega on ka Eesti traditsioonis tuntumate hulgas.

Rõžkovo virulaste populaarsemate ennustamiste hulka kuulub ka nn tumma pudru keetmine, mis Kodu-Eesti traditsioonis on esindatud märksa tagasihoidlikumalt:

Me viel mis tegime! Pidi pudrut kieta.

- Jah? Mismoodi see pudrut keetsid? [---]

- Mitmekesti nüid me siin, podruškad nüid, kolmeni, nel'lani, viieni, siss ei olnd viel kastrulit, olivad pajad. Igaühel pidi panna suola, igaühel seda jahu, igaühel valada vett.

- Ühte ja sama sellesse kastrulisse?

- Ühte sama sellesse, no vähehaavalt. Ja siss ta, igaüks pani, vottis seda suola, ta tuli nii suolane. Ja siss [---] söid seda pudrut. Hakkasid magama - üksteisega ei rääkind. Vett ka et tohtind juvva. Et siss, kes sul lieneb, see mies, see sul tuob seda vett. Vai! Vahest nii kovasti janu. - Ei! A siss seal talus pidivad keik neljani-viieni, keik pidime magada. Tougivad, rääkida ei tohtind, et kes läheks, et tuot seda vett juvva. A kesse läheb? Ah, kõik keeldusid. A pidi seda nalja teha.

- Aga kuidas seda üteldi, seda pudrukeetmist? Mis pudru see oli? [---] - Kuda me teda kutsusime - škaaputr [---] (ERA, CD 472 (5) < Mari Streit, s 1921).

[---] Siss kiedeti, ma sain kah kieta, pudrut. [---] Keikidel pidi tangu panna, keikidel vett vala ja's suola siputata. A naerda ei saand, $i$ rääkida ei saand. A poisid tulivad kiusu tegema, nied a misnibut' tegivad, et sa pidid, pidid naerma ja keik läks nurja. [---]

- Mis pudru see oli, millest sa tegid seda?

- Vaikku millest. [---] Meil rohkem öeldi niiviisi, läti viisi-määma pudru. No ta on nii kui tumma pudru [---] (ERA, CD 470 (12) < Mari Blumfert (Särg), s 1922).

Siiski on Rõžkovost teada ka üldisemat laadi tulevikuennustamisi, näiteks traditsiooniline tinavalamine. Kui tina käepärast polnud, asendas seda uuem komme - kortsutatud paberitüki põletamine:

Aga kas keegi tina ka valas? Et oleks sedasi tinast valatud?

- Valasivad tinat, kel oli. Kel ei old, paberit poletasime. A tiad, see paber jääb, paneme vastu seina, oh vaata, ooi, misle siin on, vaata, kesle hobustega. A tiad, nied paberid bõšnõi stojat - vastu seina näitab, nigu misle on. 
- Nii et panite selle paberi põlema. [---]

- Ta poles, jäi mustaks ja siis jäi nigu tuhk see kogu. A siis seinast vaatame [---] (ERA, CD 462 (21) < Miilja Kasak, s 1926).

Viimaste aastakümnetel on ennustatud näiteks ka paberitükkidele kirjutatud loosi tõmbamisega:

[---] Paberi pial kirjutasivad, seal mis oli, tommati niiviisi, segati, siis tommati, mis sial paberi peal oli. [---] Miski sõna kirjutasid, siis segasid, siis tommasid, mis seal oli [---] (ERA, CD 470 (11) < Mari Blumfert (Särg), s 1922).

Tänapäeval on pühadeaegne ennustamine Rõžkovos nagu Eestiski pigem mänguline lõbustus, mitte tõsine ettevõtmine. Ennustamisest rääkides märgitaksegi: [---] Saime me'gi nalla teha, vorožaitada [---] (ERA, CD $462(21)<$ Miilja Kasak, s 1926).

Rõžkovo virulased tähistavad tänapäeval küll jõulupühi ja need on seltskonnalembelisemad kui kodueestlastel, kuid tähtsamal kohal on neil siiski aastavahetusepidustused. Jõulude varju jäämist soodustas kindlasti ka siberlaste kollektiivsem elulaad, mis ei soosinud kitsalt perekondlikke pühi. Nõukogude perioodil ju avalikult jõule tähistada ei tohtinud.

Üllatav on aga kolmekuningapäeva vähene populaarsus Rõžkovos. Näiteks jordanivee kojutoomisest ja kasutamisest siin vastupidiselt mitmetele Siberi eesti asundustele (vt nt Korb 1998: 96-97, Korb 1999: 168-170) teated puuduvad.

\section{Vastla- ja tuhkapäev, maslenitsa}

Vastlapäev (nimetatud ka lihaheite- ja liugupäevaks), mis Kodu-Eesti traditsioonis tänini liulaskmise, eriliste toitude (nt vastlakuklid, oasupp) ning laste ja noorte lõbutsemisega tähtsal kohal, on Rõžkovos peaaegu unustuse hõlma vajunud. Vastlapäeval hobustega mööda küla sõitmist veel mäletatakse, kuid tänapäeval traditsiooni enam ei järgita:

[---] A vastlapäeval sõitsivad müöda uulitsat, et head linad kasvavad. Mõned tegid koerust, luomanaha pial sõitsivad (EFA I 57, 11 (21) < Emilia Naarits (Kodasma), s 1916).

Ka mujal Siberi eesti külades, samuti Ida-Eestis on olnud kombeks hobustega vastlasõitu teha, sama on tuntud venelaste maaslenitsa-traditsioonist (Lätt 1970: 90; Sokolov 1941: 147). 
Eestis peeti vastlapäeva naiste pühaks ja naistel oli sel päeval keelatud käsitöö tegemine (Lätt 1970: 93). Rõžkovos mäletati vastlapäevast õmblemiskeeldu:

[---] Vastlapäev ei annetud miski teha nõelaga, et siss hakkavad luomad rammitsema, lammad ja keik [---] (ERA, CD 458 (2) < Selma Ignatovitš, s 1923).

Vastlapäevale järgnevast tuhkapäevast teati Rõžkovos eelkõige taimekasvatuse ja kahjurite hävitamisega seonduvat:

Tuhka külvati uulitsale, et siis ei tule uss kapsa piale (EFA I 57, 11 (22)

$<$ Emilia Naarits (Kodasma), s 1916).

Tuhkapäe ka oli, tuhkapäe, et ei huoli jahut sõeluda, et siss lieneb suvel pallu kärbseid (ERA, CD 458 (3) < Selma Ignatovitš, s 1923).

\section{Paastumaarjapäev}

Paastumaarjapäev on tuntud olulise kevadtalvise pühana, mis märgib nii kevade algust kui ka naistepüha ning millega on seotud olnud mitmed maagilised toimingud.

Paastumaarjapäeva, Rõžkovos nimetatakse lihtsalt maarjapäev, teatakse kui Mari nimepäeva ja sellest on kujunenud naistepüha nagu enamikes Siberi eesti külades (vt Hiiemäe 1998: 110). Tavaks oli koguneda Mari-nimeliste poole ja neile ka kingitusi viia:

Maarjapäävad meil peati heaste. Kus Mari oli, sinna korjusime kokku ja hurratasime Maril ja viisime podarkaid ja [---] (ERA, CD 458 (4) < Selma Ignatovitš, s 1923).

Noh, kes Mari on, see istusime ja kus pidasime niiviisi tšaiut joime ja. Mul endal oli ode Mari, me käisime tihtipial, teda katšali ja siis ostad, mis tal viid ja [---] (ERA, CD 464 (15) < Emilia Jurjeva, s 1919).

Rõžkovos (nagu mõnedes Omski oblasti algselt eesti küladeski) on tuntud Eesti kalendritavandis ristipäeva (Hiiemäe 1984: 173), aga vene folklooris just paastumaarjapäeva (Tšitšerov 1957: 17) juurde kuuluv ütlemine:

[---] Maarjapäe suur püha ja keik. Ja ei saa, tüdruk ei saa piad kammida ja lind pesa ei tie, niuksed jutud olivad [---] (ERA, CD $461(4)<$ Emilia Naarits (Kodasma), s 1916). 


\section{Jüripäev}

Jüripäev, Eestimaal varem oluline majanduselu tähis (Hiiemäe 1984: 9), on kaotanud oma tähenduse, nüüd on esiplaanil jüritule tegemine ja organiseeritud jürijooksud. Mõne piirkonna Siberi eestlaste traditsioonis on jüripäev tänini tähtsal kohal (vt nt Korb 1999: 179-181), Rõžkovos sellel enam erilist kandepinda pole - talletada õnnestus vaid karjakasvatuse edendamisega seotud teade:

Jüripäe naised, me aga nigu kuuleme, et on, a enne olivad vanad eided juonuvad jüripäeva, et lehm annab siis pallu piima, kui jüripäe juovad [---] (ERA, CD 461 (5) < Emilia Naarits (Kodasma), s 1916, ja Jaan Jurjev, s 1933).

Viimane komme oli Eestis 20. sajandi alguses levinud Kirde-Eestis (Hiiemäe 1984: 10-11).

\section{Kokkuvõtteks}

Külati ja piirkonniti on Siberi eestlaste rahvakalendris küll erijooni, kuid vanemate väljasaadetute poolt asutatud külade, mille hulka kuulub ka Rõžkovo, kalendritavand pole tänapäeval väljarännanute omast mitmekesisem. Sealset rahvakalendrit on enim kujundanud kodumaalt kaasavõetu, ka luterlik traditsioon, lähinaabritelt lätlastelt ja enamusrahvalt venelastelt laenatu. Naabrite kombestikuelemente on sobitatud nii oma traditsiooniga kui osaletud ka võõras kombestikus seda omaks pidamata. Soodustavaks teguriks on siin arvukad segaabielud.

Rõžkovo kalendritavand on paljude aastate jooksul olnud tugeva ideoloogilise surve all, seda on omalt poolt kujundanud ka kohalikud õpetajad ja kultuuritöötajad, kelle sihtrühmaks olid eelkõige noored. Traditsioonis on vähemoluline taandunud, kuid mitmed tähtpäevad on püsinud üllatavalt elujõulise ja kombestikurikkana. Seega on Rõžkovo virulaste kalendritavandile iseloomulik, et üksikud rahvakalendri tähtpäevad (jaanipäev, lihavõtted, aastavahetus) tõusevad eriliselt esile, teistest räägitakse kui kunagi olnud traditsioonist (nt mardi- ja kadripäev) ning osa kalendritähtpäevi on tänaseks vajunud ilmselt unustusehõlma.

Põllupidamise ja karjakasvatusega kui rõžkovolaste põhiliste elatusaladega seotud kalendrikombestik on suuresti taandunud paremini traditsioonis püsinud lõbustusliku iseloomuga kalendritavandi ees. Virulaste tähtsa- 
mat püha jaanipäeva aktsepteerivad töövaba päevana nüüdseks ka venekeelsed ülemused ning sellest on saanud suur suvine pidu, kuhu tullakse ka ümberkaudsetest vene küladest.

Vanad pühad on küll teisenenud ja sulandanud endasse nõukogulikke traditsioone, kuid nn puht nõukogude pühad pole Rõžkovo virulaste traditsioonis kanda kinnitanud.

\section{Sõnaseletused}

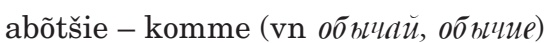

adnorjadki - üherealised lõõtspillid (vn однорядка, однорядки)

arestovat - arreteerima (vn apecmobamb)

artlis - koos

babuška - eit, vanaema (vn бабуนuka)

boletška - puuhalg (vrd vn полено)

bõli - olid (vn бъเmb, бъциu)

bõšnõi - kohev (vrd vn пьцинъцй)

daže - isegi (vn $\partial a \nVdash e)$

dom kul'tuura - kultuurimaja (vrd vn дол культурьц)

dorožili - hindasid, pidasid kalliks (vn дорожить, дорожили)

eta - see (vn $3 m o)$

gosti - külla (vrd vn zocmumb, $b$ гости)

gul'atasivad - pidasivad pidu (vrd vn гулянље)

hot' - ehhki, kas või (vrd vn xomb)

Hristos (Kristos) voskres! - venekeelne lihavõttepühade aegne tervitus: Kristus on üles tõusnud! (vn Xpucmoc bockpec!)

Voistenno voskres! - venekeelne kombekohane vastus tervitusele: Tõesti, ta on üles tõusnud! (vn Boucmuнy bockpec!)

$\mathrm{i}-\mathrm{ja}(\operatorname{vn} u)$

karassiinat - lambiõli (vrd vn керосин - petrooleum)

kastjor - lõke (vn kocmëp)

katšali - kiigutasid (vn kayamb, kayaлu)

kluuba - klubi (vrd vn $k \cdot \Omega y \sigma)$

konfetit - kompekke (vrd vn конфетка)

krestovaitama - ülestõusmispüha õnnesooviks kolm korda suudlema (vrd vn xpucmoсоватьс $я)$

kruonusi, kruonid - pärgasid, pärjad 
Anu Korb

Kruutudest - Krutinkast (vrd vn Kрутинкa)

kummi - vader (sm kummi, vrd vn $k y \cdot u$ )

lieneb - vist on, saab olema (vrd sm lienee)

maslenkast - võinädalast (vrd vn «асленииа)

nastojašad - tõelised (vrd vn настояиий)

ne abežali - ei solvanud (vrd vn не обежали)

nibut' - miski, midagi (vrd vn нибуть)

ossobenna - eriti, iseäranis (vrd vn особенно)

padrugaga, padruška - sõbrannaga, sõbrannake (vn noдpyza, nодpyuka)

patšot - au sees (vrd vn noчem)

piiva - õlu (vrd vn nubo)

pilmenid - pelmeenid (vrd vn пельлени)

pimmi - viltsaabast (vrd vn $n u, u$ )

podaite krasnuju jaitsu - vn: andke punast muna (подайmе красную яиу)

podarkaid - kingitusi (vrd vn noдарок)

polnomotšias - volinik (vrd vn полнолочие)

prasmeivali - naersivad välja, tegid naerualuseks (vrd vn ирослеивать)

prigonasse - loomade varjualusesse (vrd vn пригон)

primer - näiteks (vn прилер)

prosta - lihtsalt (vn npocmoü)

rammitsema - lonkama

rankusi - puupakke?

ras - kord (vrd vn pas)

rehelised - siin: rahul (vrd sm rehellinen)

repressia - represioon (vn penрессия)

Saberutsa v adin dom, tšaijujut, sidjat, razgavarivajut, apjat tšaijujut - vn: kogunevad ühte majja, joovad teed, istuvad, jutustavad, joovad jälle teed (соберают 6 один дол, чаюют, сидят, разговаривают, опять чаюют)

sedmova janvarja do desjatovo - vn: seitsmendast jaanuarist kuni kümnendani (седлюго яньваря до десятого)

stojat - seisavad (vn cmoumb, стояm)

stopkat - viinapitsi (vrd vn $c m o n k a)$

strääbanid - küpsetised (vrd vn стряпня)

sumkadega - kottidega (vrd vn cy.ıka)

sõr - juust (vrd vn çıp)

škaaputr - nn tumma pudru, määma pudru (aastavahetuspidustuste ajal ennustamiseks tüdrukute ühiselt keedetud puder, kuhu igaüks paneb suvalise koguse 
tangu, vett ja soola, kuid mille söömise ajal ja järel ei tohtinud naerda ega rääkida)

školnikud - kooliõpilased (vrd vn икольник)

zagadõvajut - ennustavad (vn заzadamb, заzaдььbamb, завадают)

zakon - seadus (vn зakoH)

želotš - kollatõbi (vrd vn *e^myxa)

taband - jätkunud

tak - nii (vn mak)

taljanka - bisonoorne üherealine lõõtspill (vn maльянка, тальян-2арлуун)

trääbati - küpsetati (vrd vn стряпать)

tšaiud, tšaiut - teed (vrd vn yaǔ)

ugašali, ugašoitavad - kostitasid, kostitavad (vrd vn yzouamı)

vaikku - kas või (vrd sm vaikka)

ved - ju (vrd vn bedr)

vesjöl - lõbus (vrd vn Весёльıи)

vierud - pirrud, puutikud

vobšee - üldse (vrd vn Вообще)

vorožoitasime, vorožaitas - ennustasime, ennustas (vrd vn Ворожumъ)

võhadnotti - vaba päeva (vrd vn brıxodнoǔ)

võstupajet - esineb (vrd vn bысmynamb, bыстуnaеm)

\section{Arhiivimaterjalid}

ERA, CD = Eesti Kirjandusmuuseum, Eesti Rahvaluule Arhiivi heliahriiv, digitaalsalvestused CD-del

EFA = Eesti Kirjandusmuuseum, Eesti folklooriarhiivi rahvaluulekogu (Eesti Rahvaluule Arhiivi kogu alates 1996. aastast)

ERA, VF = Eesti Kirjandusmuuseum, Eesti Rahvaluule Arhiivi fotokogu, värvifotod

\section{Kirjandus}

Aleksejevski 2004 = Алексеевский, Михаил Д. Советские праздники в русской деревне: К постановке проблемы. Дранникова, Наталья В. (koost). Maтериаль VI Международной иколь иолодого фольклориста: (22-24 ноября 2004 года): (Лаборатория фольклора ПГУ илени М. В. Лолонособа). Архангельск: Поморский университет. 
Beitl, Richard \& Erich, Oswald A. 1955. Wörterbuch der deutschen Volkskunde. 2. väljaanne. Kröners Taschenausgabe 127. Stuttgard: Kröner.

BERTA 2004 = BERTA. Eesti rahvakalendri tähtpäevade andmebaas (http://www. folklore.ee/Berta - 6. aprill 2006).

Dal 1957 = Даль, Владимир И. Пословици русского народа. Москва: Художественная литература.

Eisen, Matthias Johann 1920. Eesti uuem mütoloogia. Eesti mütoloogia 2. Tallinn: Rahvaülikool.

ERlA 1969 = Tedre, Ülo (toim). Eesti rahvalaulud: Antoloogia 1: 2. Tallinn: Eesti Raamat (http://www.folklore.ee/laulud/erla/ - 6. september 2006).

Fehrle, Eugen 1955. Feste und Volksbräuche im Jahreslaufeuropäischer Völker. Kassel: Hinnenthal.

Granö, Johannes Gabriel 1905. Siperian suomalaiset siirtolat. Fennia 22:4. Helsinki: Suomen maantieteellinen seura.

Hiiemäe, Mall (koost) 1981. Eesti rahvakalender 2: Rahvapärimusi alates kevadisest pööripäevast ja lõpetades lihavõttepühadega. Tallinn: Eesti Raamat.

Hiiemäe, Mall (koost) 1984. Eesti rahvakalender 3: Jüripäevast viidipäevani. Tallinn: Eesti Raamat.

Hiiemäe, Mall (koost) 1985. Eesti rahvakalender 4: Suvisest pööripäevast olevipäevani. Tallinn: Eesti Raamat.

Hiiemäe, Mall (koost) 1994. Eesti rahvakalender 6: Rahvakombeid ja-uskumusi. Tallinn: Eesti Raamat.

Hiiemäe, Mall (koost) 1995. Eesti rahvakalender 7: Rahvakombeid ja-uskumusi. Tallinn: Eesti Raamat.

Hiiemäe, Mall 1998. Siberi eestlaste kalendritavandi kujunemise lugu. Tuisk, Astrid (toim). Eesti kultuur võõrsil: Loode-Venemaa ja Siberi asundused. Tartu: Eesti Kirjandusmuuseum, lk 105-125.

Hiiemäe, Mall (koost) 1999. Eesti rahvakalender VIII. Tallinn: Eesti Raamat.

Hndwb 1931-1932 = \& Bächtold-Stäubli, Hanns \& Hoffmann-Krayer, Eduard (koost). Handwörterbuch des deutschen Aberglaubens 4. Handwörterbücher zur deutschen Volkskunde 1. Berlin \& Leipzig: de Gruyter.

Jürgenson, Aivar 2000. Kirik ja kool Siberi eesti asundustes. Raudkivi, Priit et al. (toim). Acta Historica Tallinnensia: Tallinna Ülikooli Ajaloo Instituudi ja Eesti Teaduste Akadeemia ühisväljaanne = Official Publication of the Institute of History of Tallinn University and the Estonian Academy of Sciences 4. Tallinn: Teaduste Akadeemia Kirjastus, lk 31-48.

Jürgenson, Aivar 2002. Siberi eestlaste territoriaalsus ja identiteet. Tallinna Pedagoogikaülikooli humanitaarteaduste dissertatsioonid 7. Tallinn: Tallinna Pedagoogikaülikooli Kirjastus. 
Kabašnikov et al. 1993 = Кабашников, Константин П. et al. (toim). Восточно-Cлавянский фольклор: Словарь науцной и народной терлинологии. Минск: Навука и техника.

Korb, Anu (koost) 1998. Seitse küla Siberis. Eesti asundused 3. Tartu: Eesti Kirjandusmuuseum.

Korb, Anu (koost) 1999. Taaru-tagused ja stepiasukad. Eesti asundused 4. Tartu: Eesti Kirjandusmuuseum.

Korb, Anu. 2005. Venemaal rahvuskaaslasi küsitlemas: Folkloristliku välitöö metoodilisi aspekte. Studia Ethnologica et Folkloristica Tartuensia 9. Tartu: Tartu Ülikooli Kirjastus.

Lätt, Selma (koost) 1970. Eesti rahvakalender 1. Tallinn: Eesti Raamat.

Propp 2004 = Пропп, Владимир Я. Русские аграрнье ираздники: (Oпьт историкоэтнографического исследования). Москва: Лабиринт.

Sahharov 1885 = Сахаров, Иван П. Сказанія русского народа: Народныци дневникъ: Праздники и объцаи. Санкт-Петербург.

Sokolov 1941 = Соколов, Юрий М. Русский фольклор. Библиотека учителя. Москва: Учпедгиз.

Šmits, Pēteris (koost) 1940. Latviešu tautas ticējumi 2: Grābeklis - Maizes diena. Latviešu folkloras krātuves materiali A.7. Riga: Latviešu folkloras krātuve.

Zolotova 2005 = Золотова, Татьяна Н. Народный календарь: Календарные праздники. Жигунова, Марина А. \& Томилов, Николай А. (koost \& toim). Pyсcкuй народньй праздник: Научно-летодическое пособие для работников культуры и образования. Омск: Издательский дом Наука, lk 18-88.

Talve, Ilmar 1961. Keinu ja keinuminen Suomessa. Scripta Ethnologica 11. Turku: Turun yliopiston kansatieteen laitos.

Tšitšerov 1957 = Чичеров, Владимир И. Зилний период русского зелледельческого календаря XVI-XIX веков: (Очерки по истории народных Верований). Труды Института этнографии им. Н. Н. Миклухо-Маклая: Новая серия 40. Москва: Издательство Академии наук СССР.

Vītoliņš, Jēkabs 1973. Gadskārtu ieražu dziesmas = Календарные обрядовые песни. Latviešu tautas mūzika. Riga: Zinātne.

Vahtre, Lauri 1991. Eestlase aeg: Uurimus eesti rahvapärase ajaarvamise ajaloost. Tallinn: Eesti Teaduste Akadeemia.

Viikberg, Jüri \& Vaba, Lembit 1984. Siberi põhjaeestlasi kõnetamas. Keel ja Kirjandus 3, lk 145-156 \& 4, lk 210-223.

Õunapuu, Piret 2001. Pühad ja kombed. Tallinn: Tänapäev. 


\section{Summary}

\section{Folk Calendar of Virulased in Ryzhkovo Village}

Anu Korb

Key words: Diaspora, Estonians, community, multicultural, folk calendar, Siberia, Finnish

The article explores the folk calendar tradition of a mixed Estonian and Finnish lore group (called virulased) settled in the village of Ryzhkovo. The village was established around 1803 as an ethnically mixed Lutheran settlement in West Siberia. The material is based on fieldwork conducted by the author in the village in 1999, 2000 and 2004, and parallels have been drawn with material recorded in other Estonian and Lutheran settlements in Siberia.

The article discusses the folk calendar holidays of the ethnic group, starting from the most popular of these-Midsummer day. The author observes, to the extent enabled by the material, the changes that the calendar tradition of the community has undergone and the cause of these changes; the origins of the tradition in Pre-Christian or Lutheran tradition; the changes that the communication of settlers with their homeland have introduced; the elements that have been adopted from their closest neighbours Latvians or the Russian majority; the extent to which the traditional elements of the neighbouring peoples have been adapted in their ethnic tradition; and also the extent to which virulased have participated in foreign culture without adopting it as their own. In addition, the article analyses the impact of the long years of ideological pressure on the tradition of the community. 